\title{
Effect of Competitive Strategies on Performance of Micro- Finance Institutions in Kenya.
}

Mahogo Lilian Wanjiku, Jared Deya

To Link this Article: http://dx.doi.org/10.6007/IJARAFMS/v11-i1/9647

DOI:10.6007/IJARAFMS /v11-i1/9647

Received: 18 January 2021, Revised: 11 February 2021, Accepted: 28 February 2021

Published Online: 21 March 2021

In-Text Citation: (Wanjiku \& Deya, 2021)

To Cite this Article: Wanjiku, M. L., \& Deya, J. (2021). Effect of Competitive Strategies on Performance of MicroFinance Institutions in Kenya. International Journal of Academic Research in Accounting Finance and Management Sciences, 11(1), 407-422.

\section{Copyright: @ 2021 The Author(s)}

Published by Human Resource Management Academic Research Society (www.hrmars.com)

This article is published under the Creative Commons Attribution (CC BY 4.0) license. Anyone may reproduce, distribute, translate and create derivative works of this article (for both commercial and non-commercial purposes), subject to full attribution to the original publication and authors. The full terms of this license may be seen at: http://creativecommons.org/licences/by/4.0/legalcode

Vol. 11, No. 1, 2021, Pg. 407 - 422 


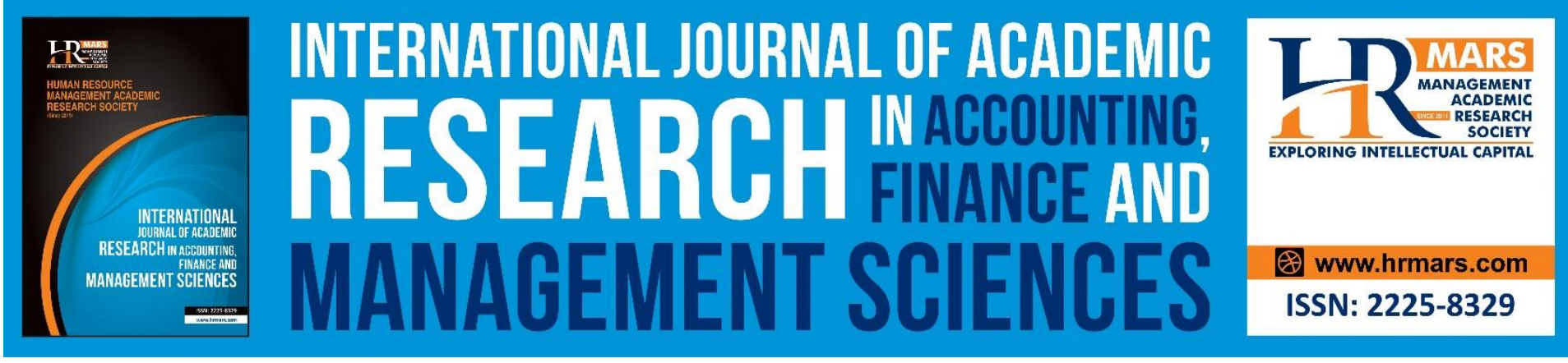

\title{
Effect of Competitive Strategies on Performance of Micro-Finance Institutions in Kenya.
}

\author{
Mahogo Lilian Wanjiku
}

Masters Degree in Business Administration (Strategic Management), School of Business and Entrepreneurship, Jomo Kenyatta University of Agriculture and Technology (JKUAT), Kenya.

Email: lilianmahogo@gmail.com

\section{Dr. Jared Deya}

Lecturer; School of Business and Entrepreneurship, Jomo Kenyatta University of Agriculture and Technology JKUAT), Kenya.

Email: jdeya@jkuat.ac.ke

\begin{abstract}
The background circumstances presently confronting Micro Financial Institutions are diverse from those of previous periods. They have experienced incredible high-tech fluctuations, economic uncertainty, stiff rivalry, swift societal variations and administrative rules. These variations in the commercial setting decide the accomplishment and effectiveness of Micro Financial Institutions. Statistics reveal that the stiff competition in Kenyan financial industry has seen the involvement of the industry to the gross domestic product in terms of their assets reduce and that the highly volatile financial environment has led to an upsurge in nonrepayment of debts in the financial sector. With the control of the interest rates, the focus of the borrowers has shifted from the Micro Financial Institutions, which charge high interest rates to commercial banks, which charge below fourteen percent. As a result, the Micro Financial Institutions are facing a challenge and to survive, there is a need to adopt competitive tactics. This study wanted to evaluate the effect of competitive strategies on performance of Micro Financial Institutions. Precisely, the study pursued to establish the effect of cost leadership strategy on performance of Micro-Finance Institutions in Kenya following Interest Rate Cap, to determine the effect of differentiation strategy on performance of Micro-Finance Institutions in Kenya following Interest Rate Cap, to examine the effect of focus strategy on performance of Micro-Finance Institutions in Kenya following Interest Rate Cap and to establish the effect of innovation strategy on performance of MicroFinance Institutions in Kenya following Interest Rate Cap. This study used the Porter's Competitive Advantage Theory, the Resource Based Theory of competitive advantage and Roger's diffusion theory of innovation to explain the relationship between the study variable. The study collected primary data using questionnaires. A descriptive survey design was adopted. The Target population comprised of all the 13 licensed MFIS by the Central Bank of Kenya as at the year 2019. A census was conducted on all the 13 MFIs. The unit of observation
\end{abstract}


MANAGEMENT SCIENCES

Vol. 11, No. 1, 2021, E-ISSN: 2225-8329 @ 2021 HRMARS

was heads of corporate banking, Information Technology, Retail banking, Marketing and strategic unit of each MFI. The total target was therefore 65 respondents. Information assembled was scrutinized by aid of descriptive and inferential statistics ranging from frequencies, percentages, correlation and regression. Statistical Package for Social Sciences version 22 was used for Data Analysis. The study found out the Cost leadership strategy, Differentiation strategy, Focus strategy and Innovation Strategy significantly and positively affected the performance of Microfinance institutions in Kenya. The study recommends that cost leadership strategy is an important strategy embraced by MFIs to enable them survive competition in the market. Secondly, MFIs need to understand how to differentiate their products in the market. Third, MFIs need to focus in a given market and provide excellent products to be able to grow. Lastly, MFls need to embrace innovation as a strategy to drive their competitiveness in the financial markets. It is suggested that another study be done using SACCOs in order to develop a broader perspective of Performance using the same objectives. In addition, another study can be undertaken on commercial banks in Kenya to find out the effect of competitive strategies on their performance.

Keywords: Competitive Strategies, Performance, Micro-finance Institutions.

\section{Introduction}

Competitive strategies are those policies and tactics which a business uses and applies to make or be more preferred by customers to its rival company. Companies as well corporate organizations applies competitive strategies in their quest to ensure that they have an upper hand in the market and attract potential buyers (Nyachwaya \& Rugami, 2020). According to Powell, et al. (2015), the objective of applying competitive strategies in the organization is to knock off the socks off the competitors by doing a better job of fulfilling customer needs and preferences. An organization is able to achieve a competitive advantage over its rival if it has some type of advantage over its competitors in attracting buyers and managing with competitive forces. There are many ways of obtaining a competitive advantage, but all of them are regards to providing customers with what they perceive to be superior value compared to offerings of rival sellers (Gatutha \& Namusonge, 2020). Superior value may mean a good product at reduced cost, superior product that is worthy paying more for or a best value offering that represents an amalgamation of value, features, superiority, service, and other attractive characteristics (Aguoru, Umogbai, \& Ozowa, 2018). There are numerous distinctions in the competitive strategies that an organization engages, because each organization's strategic approach involves custom-designed approach to fit its own situations and industry setting (Ansoff, Kipley, Lewis, Stevens, \& Ansoff, 2018).

There are five distinct competitive strategies, namely, low-cost provider strategy, Broad differentiation strategy, A best cost provider strategy, A focused (market niche) strategy based on low cost and finally, A focused (or market niche) market niche based on differentiation (Ansoff, Kipley, Lewis, Stevens, \& Ansoff, 2018). A low-cost provider strategy endeavors to achieve lower overall costs than the competitors and alluring to a broad range of customers, basically by underpricing rivals (Aguoru, Umogbai, \& Ozowa, 2018). A broad differentiation strategy seeks to differentiate the company's product offering from rivals' in ways that appeals to a broad spectrum of buyers (Karyani \& Rossieta, 2018). A best-cost provider strategy gives customers more value for their money by integrating good-toexcellent product qualities at a lower cost than rivals; the target is to have the lowest (best) costs and prices compared to rivals offering products with comparable attributes. A focused (or market niche) strategy based on low costs--concentrating on a narrow buyer segment and 
MANAGEMENT SCIENCES

Vol. 11, No. 1, 2021, E-ISSN: 2225-8329 @ 2021 HRMARS

outcompeting rivals by having lower costs than rivals and thus being able to serve niche members at a lower price (Abdolshah, Moghimi, \& Khatibi, 2018). A focused (or market niche) strategy based on differentiation-concentrates on a narrow buyer segment and outcompeting rivals by offering niche members customized attributes that meet their tastes and requirements better than rivals' products (Aguoru, Umogbai, \& Ozowa, 2018).

\section{Statement of the Problem}

Micro Finance Institutions in Kenya have functioned in comparatively steady setting, but currently the sector is faced with increased challenges especially from the new regulations and advanced technology. In September 2016, the Banking (Amendment) Act, 2016 came into effect and it sets the highest and the lowest amounts in terms of percentages to be charged to borrowers by the financial institutions (CBK, 2019). This interest rate capping has placed the competition among the MFIs at level ground, with no MFI having an advantage over another in terms of lending and deposit rates. As a consequence, the new regulation has even made it worse for the MFIs to compete with the commercial banks in lending since most MFIs cannot afford to lend below the rate of $14 \%$ thus forcing customers to switch to banks for loans at the expense of MFIs.

As a result of the new regulations, the performance of MFIs as noted by the CBK (2019) report has continued to worsen year after year. The microfinance banks recorded an unassertive drop in development in 2017 with a Seven percent drop in net possessions compared to the tendency witnessed in 2016 where net assets raised by five percent and the year 2015 where it grew by 22\%. Total loans also dropped by $9 \%$ in 2017 after the interest rate capping law. Furthermore, customer deposits declined by $3 \%$ in the year 2017 after the interest rate capping law. More negative trends were seen among the MFIs where a total of 2,792 deposit account holders transferred their accounts from MFIs in period of one year after the interest rate capping (CBK, 2019).

CBK (2017) report further indicated that the microfinance banks recounted a general drop in operations with a collective loss before tax of Kshs. six hundred twenty two million for the year ended 2017 as matched with a combined loss before tax of Ksh.377 million in the year 2016. The overall MFIs performance revealed a negative return on assets of $-0.9 \%$ in the year 2017 and a negative returns on equity of $-5.5 \%$ which indicates that after the introduction of the interest rate capping, MFIs have but continued to perform poorly. The report also indicated shrinkage in the loans by $8.9 \%$ compared to the previous years which show that the customers are shifting to commercial banks for loans since they are cheaper facilities.

To perform, there is a need for MFIs to refocus their competitive strategies in order to survive and thrive. Consequently, this research strives to discover some of the generic strategies the MFIs have focused on post the interest rate capping era and establish its effect on performance.

\section{Objectives of the Study}

The main objective of this study was to ascertain the effect of competitive strategies on performance of Micro-Finance Institutions in Kenya following the Interest Rate Cap. The specific Objectives were;

1. To establish the effect of cost leadership strategy on performance of Micro-Finance Institutions in Kenya following Interest Rate Cap

2. To evaluate the influence of differentiation strategy on performance of Micro-Finance Institutions in Kenya following Interest Rate Cap 
MANAGEMENT SCIENCES

Vol. 11, No. 1, 2021, E-ISSN: 2225-8329 @ 2021 HRMARS

3. To determine the effect of focus strategy on performance of Micro-Finance Institutions in Kenya following Interest Rate Cap

4. To find out the influence of innovation strategy on performance of Micro-Finance Institutions in Kenya following Interest Rate Cap

\section{Literature Review}

Theories

\section{Porter's Competitive Advantage Theory}

Pioneered by Porter (1980), this theory was a dominant theory in the 80s to explain the major forces in the market which affected firm competitive advantage and performance. The theory presents a guide to a firm's formulation of its strategies based on the characteristics of the environment that surrounds it. One of the competitive forces to be considered is the industry in which it operates in. A firm need to direct its strategy to be able to completely dominate the players in the industry.

One of the strategies to dominate the industry of operation is the focus strategy. This strategy is essential in determining where to participate and focus activities. By focusing, a firm creates its own path which would then give it an advantage over its competitors. By the time the competitors learn of this market, the existing firm will be dominant. The concentration policy has two facets. Price concentration and distinction concentration. In price concentration an organization strives for a price benefit in its focus section. In diversity emphasis an enterprise strives for distinction in its focus market. Both facets of the concentration tactics are based on dissimilarities concerning a marketer's focus section and other sections in the sector. The focus sections requisite that it either have customers with uncommon necessities or otherwise the manufacture and distribution structure that best attends the focus section must vary from that of other sector section. Price concentration utilizes variances in cost performance in selected sections, while distinction focus utilizes the unusual wants of customers in specific sections.

\section{Resource Based Theory (RBT) of Competitive Advantage}

This theory is oriented by resources owned by the organization. The resource-based theory (RBT) as a foundation for the economic benefit of an organization reclines mainly in the utilization of a package of valued physical or non-physical possessions at the organizations' utilization (Rumelt, 1984). To convert a short term economic benefit into a continuous economic benefit necessitates that these possessions are diverse in class and not seamlessly movable (Peteraf, 1993). Successfully, this interprets into valued possessions that are neither seamlessly copied nor exchangeable devoid of excessive energy (Barney, 1991). If these circumstances stands, the package of possessions can support the firms beyond ordinary earnings.

RBT elucidates that an organization's maintainable economic benefit is attained having distinctive properties which are uncommon, treasured, unmatched, non-tradable, and nonsubstitutable, as well as resources which are special to that organization (by Finney et al. 2004). These scholars transcribe around the element that an organization may reach a viable economic benefit by exceptional possessions which it possesses, and these possessions cannot be certainly be purchased, moved, or replicated, and concurrently, they increase the value of the organization while being uncommon. 
MANAGEMENT SCIENCES

Vol. 11, No. 1, 2021, E-ISSN: 2225-8329 @ 2021 HRMARS

\section{Diffusion Theory of Innovation}

This theory was advanced by (Lazarsfeld, Berelson, \& Gaudet, 1949) .Rogers (2003) elucidates how new concepts or inventions are embraced. This theory suggests that there are five qualities of an invention that distress implementation; comparative benefit, companionable, complication, experimental capacity and perceive capacity. A Relative benefit is the measure to which a development is alleged as being enhanced than the knowledge it surpasses. Rogers's theory proposes that inventions that have a distinct, explicit benefit over the preceding tactic will be more effortlessly assumed and applied. Companionable was the point to which an invention sits well with the prevailing beliefs, previous practices and desires of possible embracers. There is robust unswerving exploration indication signifying that the more harmonious the invention is, the superior the probability of embracing (Greenhalgh, Robert, Macfarlane, Bate, \& Kyriakidou, 2004) Convolution is the opinion to which a new development is professed as challenging to comprehend and practice.

\section{Conceptual Framework}

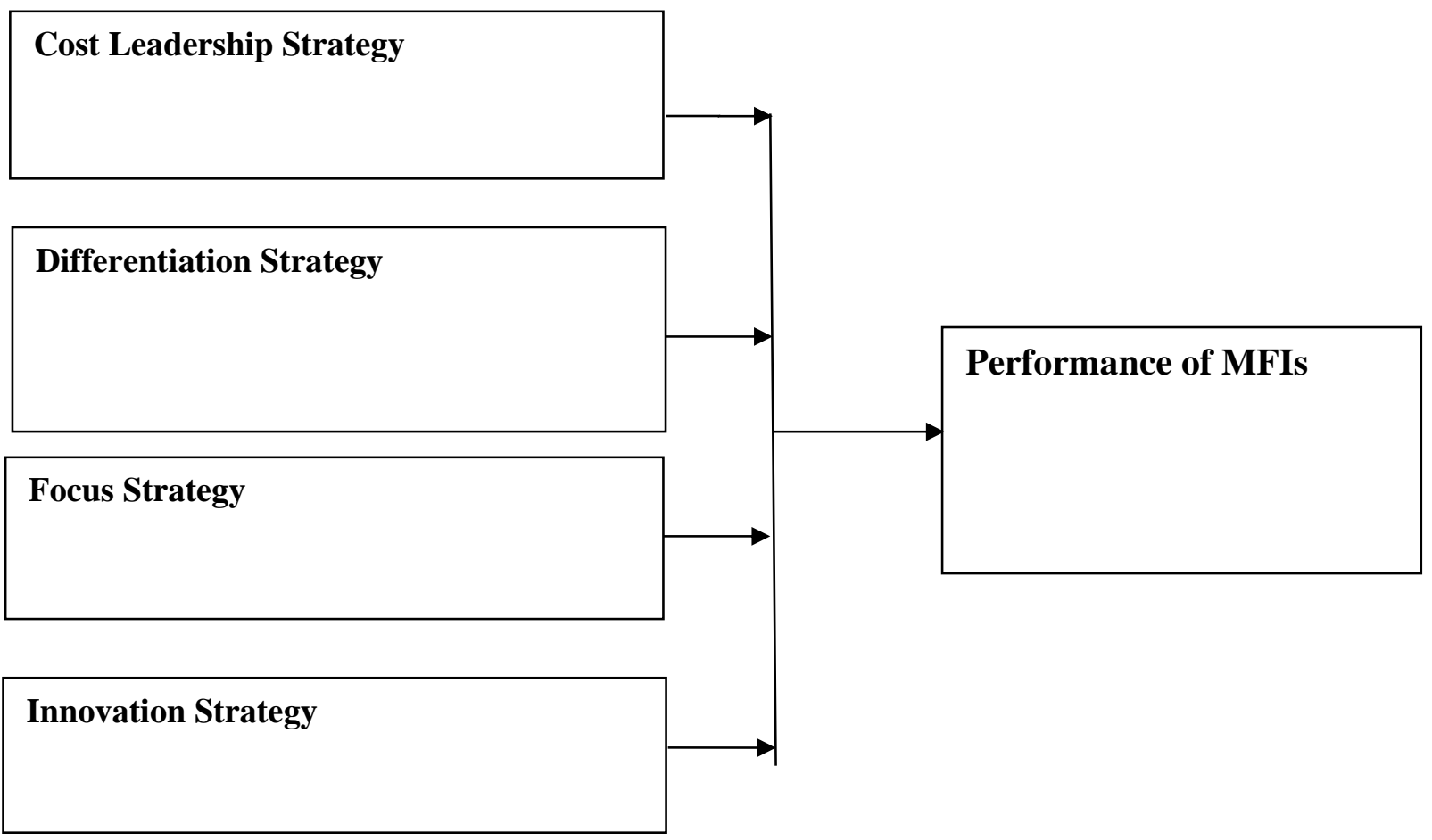

Figure 1 Conceptual Framework

\section{Methodology}

The study used descriptive as the study design for the purposes of information gathering. This design was used since it was more exact and precise. Besides, descriptive research creates measurable data about parts of a study that intrigue strategy creators. Since the study sought to test the effect of competitive strategies, this research design is suitable in gathering quantitative data to be used for analysis. The total target population was therefore the 13 MFIs licensed by the CBK (2020) while the unit of analysis was 5 representatives from each of the MFIs composing of top management teams ranging from the heads of corporate banking, Information Technology, Retail banking, Marketing and finance giving a total of 65 respondents. The sampling frame of the study comprised a collection of 65 top management employees that is heads of corporate banking, Information Technology, Retail banking, 
MANAGEMENT SCIENCES

Vol. 11, No. 1, 2021, E-ISSN: 2225-8329 @ 2021 HRMARS

Marketing and finance unit of the 13 micro financial institutions. The study made use of firsthand information that was obtained from the research's respondents and secondary data as well from the previous studies conducted. The First-hand information was assembled by aid of regulated inquiry forms and taken over a 5-point Likert scale type. The research assembled information by means of dropping and picking the questionnaires. Inquiry forms were released to the respondents and hand-picked afterwards after a period of three weeks to allow the respondents' sufficient period to answer to the inquiry forms.

The following analytical model was applied for the study;

$\mathrm{Y}=b_{0}+b_{1} \mathrm{X}_{1}+b_{2} \mathrm{X}_{2}+b_{3} \mathrm{X}_{3}+b_{4} \mathrm{X}_{4}+e$

Where:

$\mathbf{Y}=\quad$ Performance of MFIs

$\mathbf{X}_{\mathbf{1}}=$ Cost Leadership Strategies

$\mathbf{X}_{\mathbf{2}}=\quad$ Differentiation Strategies

$\mathbf{X}_{\mathbf{3}}=$ Focus Strategies

$\mathbf{X}_{\mathbf{4}}=\quad$ Innovation Strategies

$\boldsymbol{e}=\quad$ Error term

$\boldsymbol{\alpha}=$ constant

\section{Results}

The study distributed inquiry forms to 65 respondents where 56 of them were filled and returned for further analysis. This high response rate was achieved because the researcher personally issued the questionnaires and also went back to collect them. This ensured that she created a rapport with the respondents hence the high response rate. Mugenda and Mugenda (2012) notes that a reply degree of less than $30 \%$ is not viable, reply percentage of $60 \%$ is good while a reply percentage of $70 \%$ and above is excellent. This assertion by Mugenda and Mugenda (2012) agrees with the discovery of Kothari (2004) who avers that any response rate of less than $50 \%$ for a descriptive research design is unviable while a response rate of more than $70 \%$ is exceptional.

The variable cost leadership strategy had 7 factors and reliability test was carried out on the instrument and Cronbach alpha was 0.845 which was above the threshold of 0.7 . These items did not require any adjustments. The variable differentiation strategy had 7 factors and reliability test was undertaken on the instrument and Cronbach alpha was 0.824 and this figure was above the threshold of 0.700 . On the variable of focus strategy which had 5 factors reliability test was undertaken on the instrument and Cronbach alpha was 0.955 and this figure was above the threshold of 0.700 . The variable innovation strategy had 5 factors and reliability test was undertaken on the instrument and Cronbach alpha was 0.940 and this figure was above the threshold of 0.700 .

Table 1 Reliability Test

\begin{tabular}{llll}
\hline Variables & $\begin{array}{l}\text { Cronbach's } \\
\text { Alpha }\end{array}$ & $\begin{array}{l}\text { Cronbach's Alpha Based on } \\
\text { Standardized Items }\end{array}$ & N of Items \\
\hline Cost Leadership strategy & .845 & .852 & 7 \\
Differentiation strategy & .824 & .840 & 7 \\
Focus strategy & .955 & .973 & 5 \\
Innovation Strategy & .940 & .941 & 5 \\
& & & \\
\hline
\end{tabular}


MANAGEMENT SCIENCES

Vol. 11, No. 1, 2021, E-ISSN: 2225-8329 ๔ 2021 HRMARS

\section{Cost leadership Strategy and Performance}

The enquiry collected data on Cost leadership on performance of Micro-finance institutions in Kenya. Data discoveries are shown in Table 2.

Table 2 Cost Leadership Strategy and Performance

\begin{tabular}{|c|c|c|c|}
\hline Statement on Cost leadership Strategy & $\mathbf{N}$ & Mean & $\begin{array}{l}\text { Std. } \\
\text { Deviation }\end{array}$ \\
\hline The company aims for average range of customers to cut costs & 56 & 4.82 & .386 \\
\hline $\begin{array}{l}\text { The company prefers to use the range of knowledge gained } \\
\text { from previous experiences in order to cut costs }\end{array}$ & 56 & 4.88 & .334 \\
\hline The company adds new products only after market demands it & 56 & 4.13 & .489 \\
\hline $\begin{array}{l}\text { The company invests in improving processes efficiencies to } \\
\text { minimize costs }\end{array}$ & 56 & 4.97 & .478 \\
\hline $\begin{array}{l}\text { The company makes optimal outsourcing in order to manage } \\
\text { costs }\end{array}$ & 56 & 4.73 & .522 \\
\hline $\begin{array}{l}\text { The company has invested in technology to increase efficiency } \\
\text { and cut costs }\end{array}$ & 56 & 4.70 & .464 \\
\hline $\begin{array}{l}\text { The company relies on economies of scale to have a } \\
\text { competitive advantage in costs }\end{array}$ & 56 & 4.86 & .353 \\
\hline
\end{tabular}

Average

4.7

0.43

Table 2 above shows that the microfinance institutions aims for average range of customers to cut on cost where a mean of 4.82 with a standard deviation of 0.386 was established. It should be noted that Microfinance institutions are aimed at cutting costs while maximizing on their profits in their operations. A mean of 4.88 with a standard deviation of 0.334 was determined when respondents were asked whether MFIs uses the range of knowledge gained from previous experience in order to reduce their costs of operations. Additionally, the enquiry recognized that the Microfinance institutions adds new products to their range of portfolio if there is a demand in the market where a mean of 4.13 with a standard deviation of 0.489 was found. A mean of 4.97 with a standard deviation of 0.478 was determined when respondents were asked whether the MFls invests in improving processes efficiencies to reduce and minimize costs. Respondents agreed that the Microfinance institutions makes optimal outsourcing in order to manage costs where a mean of 4.73 with a standard deviation of 0.522 was established. There was an agreement from majority of the respondents that the Microfinance institutions invested in technology to increase efficiency and cut costs where a mean of 4.70 with a standard deviation of 0.464 was found. On the other hand, the study found out that the company relies on economies of scale to have a competitive advantage in costs where a mean of 4.86 with a standard deviation 0 f 0.353 was established.

Generally, with an overall mean of 4.7 it clearly indicates that microfinance institutions in Kenya were applying cost leadership to gain a competitive edge over their competitors.

\section{Differentiation Strategy and Performance}

Table 3 illustrates the outcomes that were attained after analyzing data on the second objective that intended to establish the effect of differentiation strategy on functioning of Microfinance establishments. 
Table 3 Differentiation Strategy and Performance

\begin{tabular}{llll}
\hline Statements of Differentiation Strategy & $N$ & Mean & Std Deviation
\end{tabular}

The organization concentrates on improvement of

distinctive merchandises presenting exclusive

qualities to consumers

The organization focuses on development of

exclusive services presenting exclusive qualities to

clients

The organization emphasizes on brand image as a differentiation

The company has adopted proprietary technology to offer unique services

The company emphasizes on development of goods with special features

The company emphasizes on provision of superior service compared to competitors

The company emphasizes on having a strong distributor network to differentiate it
56

$6 \quad 4.85 \quad .499$

56

4.55

.502

56

4.75

.437

56

4.63

.489

56

4.23

.853

56

4.54

.631

56

3.75

\section{Average}

4.47

\subsection{7}

The enquiry wanted to realize the effect of differentiation strategy on the performance of Microfinance institutions following the interest rate cap. Data findings are presented in table 3. A mean of 4.57 with a standard deviation of 0.499 was established when respondents were asked whether the organizations they were working for concentrates on improvement of distinctive merchandises presenting exclusive qualities to consumers. Respondents agreed that the organization focused on development of exclusive services presenting exclusive qualities to clients where a mean of 4.55 with a standard deviation of 0.502 was determined. In addition, a mean of 4.75 with a standard deviation of 0.437 was obtained when responded were asked whether the company emphasizes on brand image as a differentiation. Equally a mean of 4.63 with a standard deviation of 0.489 shows that respondents agreed to the statement that the company had adopted proprietary technology to offer unique services. This means that the individual microfinance institutions had put in place tailor made information technology which assisted them in offering unique services to their customers. On whether the company was putting emphasizes on development of goods and services with special features which are hard to imitate, a mean of 4.23 with a standard deviation of 8.53 was established. This means that the microfinance institutions were serious in developing new products to assist them in beating up competition in the market. Similarly, a mean of 4.54 with a standard deviation of 0.631 was found when respondents were asked whether the individual microfinance institutions was putting emphasis on provision of superior services as compared to their competitors. This means that microfinance institutions were 
MANAGEMENT SCIENCES

Vol. 11, No. 1, 2021, E-ISSN: 2225-8329 @ 2021 HRMARS

putting in efforts to develop offer better and improved services which are appealing to their customers and this was able to give them a competitive advantage. Similarly, respondents were indifferent on whether the company insisted on a strong network to differentiate it. Respondents were of the opinion that since microfinance institutions were small in terms of scale, they were not ready to incur a lot of costs in forming distributor network.

In conclusion the findings on differentiation strategy indicates that Microfinance institutions were using it to enhance their competitiveness in the market and improve their performance as indicated by an average mean of 4.47.It is clear that respondents agreed that differentiation strategy was key to enhancement of performance of microfinance institutions in Kenya.

\section{Focus Strategy and Performance}

The second aim was to realize the outcome of focus tactics on the functioning of Microfinance institutions in Kenya. Results of this aim are presented on Table 4

Table 4.Focus strategy and performance

Average

4.48

0.59

\begin{tabular}{llll}
\hline Statements on focus Strategy & N & Mean & $\begin{array}{l}\text { Std. } \\
\text { Deviation }\end{array}$
\end{tabular}

\begin{tabular}{lccc}
\hline $\begin{array}{l}\text { The organization concentrates on the customer } \\
\text { favorites and Centre's actions about that }\end{array}$ & 56 & 4.63 & .489 \\
$\begin{array}{l}\text { The organization focuses on the consumer tastes and } \\
\text { centers activities around that }\end{array}$ & 56 & 4.55 & .658 \\
$\begin{array}{l}\text { The company focuses on a given geographical area of } \\
\text { potential }\end{array}$ & 56 & 4.17 & .478 \\
$\begin{array}{l}\text { The company is working on a given service line to } \\
\text { specialize on }\end{array}$ & 56 & 4.43 & .850 \\
$\begin{array}{l}\text { The company is working on a given product line to } \\
\text { specialize on }\end{array}$ & 56 & 4.64 & .483
\end{tabular}

With reference to table 4 above, respondents agreed that microfinance institutions concentrates on the customer favorites and focuses their actions on it where a mean of 4.63 with a standard deviation of 0.489 was established. This deduces that the microfinance institutions goes an extra mile to understand customer needs and works towards satisfying those needs. On whether the microfinance institutions concentrates on customer tastes and works towards providing products similar to those needs, respondents agreed with the statement as shown by a mean of 4.55 with a standard deviation of 0.658 .As such, customer tastes and needs can be seen to be a driver in the innovation and designing of products in the market. A mean of 4.17 with a standard deviation of 0.478 was established when respondents agreed with the statement that the company was focusing on a given geographical area to gain a competitive advantage in the market. This means that the microfinance institutions were focusing on establishing their presence on regional areas near the customers to tap on the unbanked population. Consequently, respondents agreed that the microfinance institutions was working on a given product line to specialize on where a mean of 4.43 with a standard deviation of 0.850 . This therefore shows that the microfinance institutions were 
MANAGEMENT SCIENCES

Vol. 11, No. 1, 2021, E-ISSN: 2225-8329 @ 2021 HRMARS

determined to establish a given special service line on which they were to use to achieve a competitive improvement in the market.

This shows that focus strategy is a good strategy being used by microfinance institutions to improve productivity of employees. In general, the focus strategy came out strongly as a popular competitive strategy being used by microfinance institutions in Kenya based on an overall mean of 4.48 .

\section{Innovation Strategy and Performance}

The fourth intent was to assess the influence of innovation strategy on functioning of MFIs in Kenya following interest rate cap. The outcome of this objective is depicted on Table 5

Table 5 Innovation strategy and Performance

\begin{tabular}{llll}
\hline Statements on Innovation strategy & $\mathbf{N}$ & Mean & $\begin{array}{l}\text { Std. } \\
\text { Deviation }\end{array}$ \\
\hline $\begin{array}{l}\text { The company focuses on development of unique merchandises } \\
\text { presenting exclusive qualities to consumers }\end{array}$ & 56 & 4.63 & .489 \\
$\begin{array}{l}\text { The organization continuously focuses on improving existing } \\
\text { products }\end{array}$ & 56 & 4.70 & .464 \\
$\begin{array}{l}\text { The company has adopted proprietary technology to offer } \\
\text { unique services }\end{array}$ & 56 & 4.55 & .502 \\
$\begin{array}{l}\text { The company focuses on gaining new potential markets and } \\
\text { develops mechanisms to better serve the target market }\end{array}$ & 56 & 4.68 & .471 \\
$\begin{array}{l}\text { The company reviews function deployments and does business } \\
\text { process reengineering }\end{array}$ & 56 & 4.61 & .493 \\
\hline
\end{tabular}

With reference to Table 5, respondents approved that the company focused on development of unique merchandises presenting exclusive qualities to consumers where a mean of 4.63 with a standard deviation of 0.489 was established. As such, the microfinance institutions were deemed to be inventing new merchandizes for their customers to be more competitive than the commercial banks. Similar results were noted on improving the existing products where respondents agreed that the companies were working to ensure their existing product were improved as per customer's demands, where a mean of 4.70 with a standard deviation of 0.464 was established. This means that the companies had realized that the customers needed the existing products improved and thus the MFIs institutions worked to improve them. A mean of 4.55 with a standard deviation of 0.502 was obtained on whether the companies had adopted proprietary technology to offer unique services. This is to mean that MFls had embraced an information technology which was assisting them in the running of their daily operations.

Respondents also agreed that the companies had focused on gaining unique potential markets and develops mechanisms to better serve the target market where a mean of 4.68 with a standard deviation of 0.471.This means that the MFIs were expanding and opening new branches at their potential markets to serve their new and potential customers. The companies were noted to be reviewing function deployments and doing business process 
MANAGEMENT SCIENCES

Vol. 11, No. 1, 2021, E-ISSN: 2225-8329 @ 2021 HRMARS

reengineering and this was found to help in improving the performance of the $\mathrm{MFI}$, where a mean of 4.61 with a standard deviation of 0.493 was obtained. This means that business process re-engineering was helping the MFIs to improve their processes and rejuvenate From the general findings above, it is clear that innovation strategy as a competitive strategy had a serious implication on the performance of microfinance firms in Kenya, where a general mean of 4.63 was determined, indicating that if correctly applied by microfinance institutions, innovation strategy can lead to improvement in performance of firms.

\section{Regression Model}

The study carried out regression analysis to establish the statistical relationship between the independent variables notably $\left(X_{1}\right)$ cost leadership strategy $\left(X_{2}\right)$ Differentiation strategy, $\left(X_{3}\right)$ Focus strategy and $\left(\mathrm{X}_{4}\right)$ Innovation strategy and dependent variable $(\mathrm{Y})=$ Performance of Microfinance institutions in Kenya. These results were presented using regression analysis model summary table, Analysis of variance (ANOVA) table and beta co-efficient table.

\section{Model Summary}

Table 6 denotes the results for the model summary that was obtained on data analysis.

Table 6 Model Summary

\begin{tabular}{|c|c|c|c|c|c|}
\hline \multicolumn{6}{|c|}{ Model Summary } \\
\hline Model & $\mathbf{R}$ & R Square & Adjusted R Square & $\begin{array}{l}\text { Std. Error of the } \\
\text { Estimate }\end{array}$ & $\begin{array}{l}\text { Durbin- } \\
\text { Watson }\end{array}$ \\
\hline 1 & $.935^{a}$ & .874 & .622 & .90832 & 1.383 \\
\hline \multicolumn{6}{|c|}{$\begin{array}{l}\text { a. Predictors: (Constant), Innovation, Cost leadership, Focus, Differentiation } \\
\text { b. Dependent Variable: Performance }\end{array}$} \\
\hline
\end{tabular}

Table 6 shows $R, R^{2}$ and adjusted $R^{2}$. $R$ is the correlation among the dependent variable and predictors. $R^{2}$ is the coefficient of determinations that describes the extent to which the predictor influence variations in dependent variables while adjusted $R^{2}$ describes the extent of influence between the variables on addition of variables in the equation.

The $\mathrm{R}$ of 0.803 shows strong correlation among the variables. The $\mathrm{R}^{2}$ of 0.874 shows that 87.4 $\%$ of variations in performance is influenced by changes in cost leadership, Differentiation, focus and innovation. This means that other factors account for $12.6 \%$ of variations in performance among Microfinance institutions in Kenya.

\section{ANOVA Test}

The significance of the model was ascertained by undertaking an analysis of Variance. The outcomes are presented on Table 7 
Table 7 ANOVA Test

\begin{tabular}{|c|c|c|c|c|c|c|}
\hline \multicolumn{7}{|c|}{ ANOVA $^{a}$} \\
\hline \multicolumn{2}{|c|}{ Model } & $\begin{array}{l}\text { Sum of } \\
\text { Squares }\end{array}$ & $d f$ & $\begin{array}{l}\text { Mean } \\
\text { Square }\end{array}$ & $\mathrm{F}$ & Sig. \\
\hline \multirow[t]{3}{*}{1} & Regression & 11.430 & 4 & 2.857 & 3.463 & $.036^{\mathrm{b}}$ \\
\hline & Residual & 1.650 & 2 & .825 & & \\
\hline & Total & 13.080 & 6 & & & \\
\hline \multicolumn{7}{|c|}{ a. Dependent Variable: Performance } \\
\hline
\end{tabular}

Table 7 shows a P-value of 0.036 which shows that the overall model was significance in explaining the variations in performance among the microfinance institutions in Kenya. Data was processing at $95 \%$ confidence level which means that a statistics of below 0.05 is significant.

\section{Coefficients of Determination}

Table 8 shows the results for coefficients that show the extent and nature of relationship among the variables.

Table 8 Regression Model

\begin{tabular}{|c|c|c|c|c|c|c|}
\hline \multicolumn{7}{|c|}{ Coefficients $^{a}$} \\
\hline \multirow{2}{*}{\multicolumn{2}{|c|}{ Model }} & \multicolumn{2}{|c|}{$\begin{array}{l}\text { Unstandardized } \\
\text { Coefficients }\end{array}$} & \multirow{2}{*}{$\begin{array}{l}\text { Standardized } \\
\text { Coefficients } \\
\text { Beta }\end{array}$} & \multirow[t]{2}{*}{$\mathbf{t}$} & \multirow[t]{2}{*}{ Sig. } \\
\hline & & B & Std. Error & & & \\
\hline \multirow[t]{5}{*}{1} & (Constant) & -16.620 & 9.634 & & -1.725 & .227 \\
\hline & Cost leadership & .369 & 1.616 & .070 & .228 & .841 \\
\hline & Differentiation & 3.100 & 1.596 & .784 & 1.942 & .192 \\
\hline & Focus & .903 & 1.820 & .181 & .496 & .669 \\
\hline & Innovation & .046 & .206 & .070 & .222 & .845 \\
\hline \multicolumn{7}{|c|}{ a. Dependent Variable: Performance } \\
\hline
\end{tabular}

Table 8 shows the coefficients of the regression model that were obtained. The regression model is specified as follows:

$\mathrm{Y}=-16.620+0.369 \mathrm{X}_{1}+3.100 \mathrm{X}_{2}+0.903 \mathrm{X}_{3}+0.046 \mathrm{X}_{4}+\mathrm{e}$

-16.620 is performance of microfinance in absence of the study variables, +0.369 is the increase in performance of microfinance institutions in response to a unit increase in Cost leadership, +3.100 is the increase in performance of microfinance institutions in response to a unit increase in Differentiation, +0.903 is the increase in performance of microfinance institutions in response to a unit increase in Focus and +0.46 is a unit increase in performance of microfinance institutions in response to a unit increase in Innovation..

Additionally, the P-values on the last column on the Table 4.14 reveals that all these variables had significant role in performance of Microfinance institutions in Kenya since the significance statistic were less than 0.05 in all cases. Therefore, it can be inferred that Cost leadership strategy, Differentiation strategy, Focus strategy and Innovation strategy have a statistically significant role on performance of microfinance institutions in Kenya 
MANAGEMENT SCIENCES

Vol. 11, No. 1, 2021, E-ISSN: 2225-8329 ๔ 2021 HRMARS

This is consistent with the past theoretical and empirical studies on competitive strategies whereby firms which needs to improve their competitiveness employ strategies such as cost leadership strategy, differentiation strategy, focus strategy and innovation strategy.

\section{Conclusion and Recommendations}

The main purpose was to establish the influence of competitive strategies on the performance of Microfinance institution following the interest rate cap in Kenya. The study found out that competitive strategies have a positive impact on the performance of Microfinance institutions in Kenya.

Results of the descriptive statistics showed that cost leadership strategy had a role on the functioning of microfinance institutions in Kenya. It was found out that MFIs were investing in improving processes and efficiencies to minimize costs. In addition, it was established that MFIs were investing in minimizing costs. These results were in agreement with the inferential statistics results which recognized that Cost leadership strategy had a positive impact on the functioning of Microfinance institutions in Kenya. The regression results indicated that there was a positive influence of Cost leadership on the performance of MFIs indicating that the variable acts as catalyst to performance.

Descriptive statistics showed that Differentiation strategy advances performance of Microfinance institutions in Kenya. Interpretations showed that the use of differentiation strategy by organizations concentrating on improved distinctive merchandizes, presenting exclusive qualities to consumers, differentiation by use of brand image and provision of superior and quality products than competitors were found to be some of the differentiation strategies being employed by the MFIs to improve their performance. Similarly, these findings were supported by regression model which revealed that there was a positive effect of differentiation on performance of microfinance institutions after interest rate capping. This is an indication that differentiation strategy if well used can help organizations to improve their performance.

Result from descriptive statistic indicates that the MFIs institutions concentrates on a given product line and this helps in improving the performance of the organizations. This is due to the results that indicated that MFIs concentrates of customer favorite concentrates on consumer tastes, works on a given service line towards customer satisfaction and Focuses on a given geographical area which is potential for their growth. On the side, regression model, these findings were confirmed in that Focus strategy had positive bearing towards the performance of Microfinance institutions in Kenya following interest rate capping.

Result from descriptive statistic indicates that Innovation strategy influence was high and this led to improvement in the functioning of MFIs. This is due to the results that indicated that MFIs focused on improving existing products, they were involved in innovations to gain access to new markets, developed new unique products presenting high quality to customers and were involved in redesigning their businesses through innovative technologies. On the side, regression model, these findings were confirmed in that Innovation strategy had positive bearing towards the performance of Microfinance institutions in Kenya following interest rate capping.

\section{Suggestion for Further Studies}

The general objective of this study was to establish the influence of Competitive strategies on the performance of Microfinance institutions in Kenya. Results showed that Cost leadership strategy, Differentiation Strategy, Focus Strategy and Innovation strategy influenced the 
MANAGEMENT SCIENCES

Vol. 11, No. 1, 2021, E-ISSN: 2225-8329 @ 2021 HRMARS

performance of Microfinance Institutions in Kenya. Another study can be done among Microfinance institutions in another county in Kenya in order to compare results. Such a study together with this one can be used to make policies that can be applicable at nation-wide level.

It is equally suggested that another study be done using SACCOs in order to develop a broader perspective of performance using the same objectives. In addition, another study can be undertaken on commercial banks in Kenya to find out the effect of competitive strategies on their performance.

\section{References}

Abdolshah, M., Moghimi, M., \& Khatibi, S. A. (2018). Investigating competitive advantage in banking industry based on Porter's Generic strategies: IRANs newly-established private banks. International Journal of Applied Management Sciences and Engineering (IJAMSE), 5(1),52-62.

Aguoru, C. N., Umogbai, M. E., \& Ozowa, V. (2018). Effect of strategic analysis and strategy implementation on service quality of a popular telecommunication company in Nigeria. International Journal of Scientific Research and Management (IJSRM), 6(4), 305-311.

Ansoff, H., Kipley, D., Lewis, A., Stevens, R. H., \& Ansoff, R. (2018). Implantation strategic management. Palgrave Macmillan.

Barney, J. (1991). Firm Resources and Sustained Competitive Advantage, . Journal of Management, , 17,(1)99-120.

Brooks, C. (2008). Introductory Econometrics for Finance, 2nd Edition. Cambridge, United Kingdom: Cambridge University.

CBK. (2019, 12 31). Central Bank of Kenya. Retrieved from Central Bank of Kenya Website: https://www.centralbank.go.ke/uploads/banking_sector_reports/1308445982_Credit \%20Survey\%20Report\%20for\%20the\%20Quarter\%20ended\%20December\%202018.pd $\mathrm{f}$

Dombrowski, U., Krenkel, P., \& Wullbrandt, J. (2018). Strategic positioning of production within the generic competitive strategies. Procedia CIRP, 72,1196-1201.

Gatutha, P. G., \& Namusonge, M. (2020). Competitive strategies and the performance of supermarkets in Nairobi city,Kenya. International Academic Journal of Human Resource and Business Administration, 3(9),291-303.

Karyani, E., \& Rossieta, H. (2018). Generic strategies and financial performance persistence in the banking sector in Indonesia. Management \& Accounting Review, 17(1),15-30.

MoCDM. (2018). Ministry of Cooperative Development and Marketing:SACCOS Annual Performance Report, Murang'a County. Nairobi: Ministry of Cooperative Development and Marketing.

Nyachwaya, J. M., \& Rugami, J. M. (2020). Competitive strategies and performance of commercial banks in Mombasa county,Kenya. International Journal of Business Management, Entrepreneurship and Innovation, 2(1),65-74.

Odero, C. O., \& Rotich, G. (2016). Factors influencing strategy implementation on the performance of commercial banks in Kenya, A case of co-operative bank Bank of Kenya. Strategic journal of Business and change Management, 3(4),73 - 87.

Peteraf, M. (1993). The Cornerstones of Competitive Advantage: A Resource-Based View. Strategic Management Journal, , 4,(3),179-191.

Porter, M. E. (2008). On competition. Harvard Business Press. 
Powell, B. J., Waltz, T. J., Chinman, M. J., Damschroder, L. J., Smith, J. L., Matthieu, M. M., . . Kirchner, J. E. (2015). A refined compilation of implementation strategies:results from the expert recommendations for implementing change (ERIC) project. Implementation Science, 2-14.

Rumelt, R. (1984). Towards a strategic theory of the firm;Competitive Strategic Management,. Englewood Cliffs (NJ). : Prentice-Hall, .

Santos, J. B., \& Brito, L. L. (2017). Toward a subjective measurement model for firm performance. Brazilian Administration Review, 9(SPE), 95-117.

Sekaran, U., \& Bougie, R. (2010). Research Methods for Business: A Skill Building Approach, 5th ed. . West Sussex: John Wiley and Sons Ltd.

Wahyuni, D. (2015). The research design maze: Understanding paradigms, cases, methods and methodologies. Journal of Applied Management Accounting Research, 10(1) 69-80.

Wicker, P., Soebbing, B. P., Feiler, S., \& Breuer, C. (2015). The effect of Porter's generic strategies on organisational problems of non-profit sports clubs. European Journal for Sport and Society, , 12(3), 281-307.

Yin, R. K. (2017). Case study research and applications: Design and methods. . Sage publications.

Yoder, B. K. (2019). Retrenchment as a screening mechanism: Power shifts, strategic withdrawal, and credible signals. American Journal of Political Science, 63(1),130-145.

Zikmund, W. G., Quinlan, C., Griffin, M., Babin, B., \& Carr, J. (2019). Business Research methods. Cengage Learning EMEA. 